\title{
Gender Stereotype in Joyce Lebra's The Scent of Sake
}

\author{
Fais Wahidatul Arifatin \\ English Program, Universitas Muhammadiyah Lamongan, Indonesia \\ faisarifatin@umla.ac.id
}

\begin{tabular}{|c|c|}
\hline Info & ABSTRACT \\
\hline $\begin{array}{l}\text { Article History } \\
\text { - Article Received } \\
19^{\text {th }} \text { August } 2019 \\
\text { - Article Reviewed } \\
09^{\text {th }} \text { October } 2019 \\
\text { - Article Accepted } \\
24^{\text {th }} \text { October } 2019 \\
\text { Keywords } \\
\text { Gender } \\
\text { Stereotype } \\
\text { Liberal feminism } \\
\text { Women }\end{array}$ & $\begin{array}{l}\text { Gender stereotype should be understood as negative beliefs shared by a particular group } \\
\text { due to over-simplification and generalization. In this study, gender stereotype is used to } \\
\text { mean negative beliefs toward women, which is based on their sexual or gender identity } \\
\text { instead of their personal quality and individual competence. The writer try to show that in } \\
\text { The Scent of Sake by Joyce Lebra is considered as a novel depicting the issue of gender } \\
\text { stereotype in Japanese family culture, especially in managing the sake business which is } \\
\text { represented trough Rie as the main character. Hence, in this study try to answer What are } \\
\text { gender stereotypes experienced by Rie as reflected in Joyce Lebra's The Scent of Sake and how } \\
\text { does Rie struggle against gender stereotype as reflected in the novel. The research design } \\
\text { used by the writer is literary criticism; it is liberal feminism especially the theory of Mary } \\
\text { Wollstonecraft. The results of the study show that women as represented by Rie, is } \\
\text { stereotyped in the family's sake business through many negative stigmas. Such stereotypes } \\
\text { have given negative influences toward Rie in terms of marginalization in management, in } \\
\text { educational access and women's lack of decision making in marriage. To reduce the effects, } \\
\text { Rie struggles against gender stereotype by performing the stereotypes. Through } \\
\text { considerable struggles, Rie has proven that women should not be viewed as inferior to men. } \\
\text { Rie has tried very hard to play an active role as a subject in her own family's business of sake } \\
\text { production. }\end{array}$ \\
\hline
\end{tabular}

\section{INTRODUCTION}

Since the $19^{\text {th }}$ century, the issue of man and woman relation has been widely discussed in both western and eastern societies. Some culture represents and portrays men as more superior than women. For example, in the early 1970s, Schein[1] revealed from her empirical investigation that "think manager - think male" was strongly believed as the major principle for managers in the United States. Schein examined how many managers possessed successful characteristics, attitudes, and temperaments, and whether those attributes were more common to men in general than to women. He concluded that men were inherently so superior than women that they had more possibility for a success than women did.

Gender stereotype is the representation, which is mostly wrong, of men and women triggers. Such a stereotype is related to cognitive processes because people have different expectations for female and male behavior, and the traditional gender roles help to sustain the expectations. For example, males are supposed to be brave, assertive, aggressive, independent, and task-oriented; whereas, females are seen as more sensitive, dependent, emotional, and people-oriented. The expectation drives people's attitude toward males and females and how they are 
supposed to behave. Such a mechanism show gender stereotype is sharpened by the cognitive process.

According to Hendry[2], gender stereotype is related not only to the cognitive process but also to "the indigenous family system where men were superior to women, who were expected to attend to man's every need". For example, true women are commonly expected to deal with domestic affairsmaking a home and having children, "The true woman's place was as daughter, sister, but most of all as wife and mother". These domestic duties include cooking and nursing the sick, especially a sick husband or child. In short, the indigenous family system directly or indirectly- influences the existence of gender stereotype, as well as the cognitive process does, in most of the world culture.

The occurrence of gender stereotyping as resulted from and sustained by both the cognitive process and the indigenous family system is evident even in a developed country like Japan. This idea encourages most Japanese women to stay home doing the housework and taking care of their families, while the men are considered as the foremost financial providers for the family[2][3].

Since Japanese society takes this notion, women's work patterns are unique with regard to those of women in Western industrial countries. A vast majority of Japanese women want to stay home after getting married because they believe that being mothers and wives is their responsibility. Moreover, most husbands still want their wives to adhere to this traditional idea[2]. This generates gender inequality at the workplace and home.

The issue of gender inequality also becomes the focal point in literary criticism. It shows how women's literature has evolved, starting from the Victorian period to modern writing. She breaks down the movement into three major stages: "The Feminine", a period beginning with the use of male pseudonyms in the 1840s until 1880 with George Eliot's death; "The Feminist", from 1880 till the winning of the vote in 1920; and "The Female", from 1920 till the presentday, including a "new stage of self-awareness" about 1960.
Female writers of the last period tend to inscribe with feminine awareness in mind. The subordinate sex is lashed out against the traditional standards and values, demanding its rights and sovereignty to be recognized. Women's literature of such a phase vents the sense of injustice in remarkable manner. Woman writers expand their sphere of influence by making inroads into social work.

One of the most notable writers is the American Historian Joyce Lebra, who writes a great novel of The Scent of Sake (2009) containing some issues of gender stereotype in Japanese traditional business of sake. As The Scent of Sake is written by an American novelist, it provides some data on gender relation of eastern society viewed from western perspective. The novel narrates about a woman's struggle for equality in managing the so-argued male business.

The novel portrays $19^{\text {th }}$ century Japanese women who are commonly forced to "kill the self." The disgrace is experienced, for the best example, by the main character, Rie, who cannot freely do what she wants. As the daughter of Omura family, Rie is demanded to affirm the "ideal quality" of a female child as commonly accepted by the ancestral culture and the social tradition. Due to gender stereotype, Rie cannot entirely take part in managing the commerce of sake. When a woman enters the brewery and the myth is the sake turns to sour. Then, the myth has victimized Rie in even the business domain of her own family.

The harsh label upon Rie overlooks the fact that, after the death of her brother, the future of Omura House rests with her as the only child in the family. Although she actually has an "innate right" to maintain the honour and prosperity of the house, she is averted from such a possible role due to her gender identity as a woman. In short, The Scent of Sake has markedly portrayed the issue of gender stereotype through the dilemmatic position of Rie in running the family business of sake.

Along with the aforementioned depictions, the writer decides to analyze The Scent of Sake using feminist literary criticism. The approach aims at criticizing the classical, underestimating view on 
women and struggling for their better position in the society so that all women will neither see themselves nor be seen as "no significant other." Feminism seeks for gender equality because women should possess the same privileges and rights as men do.

The novel, which represents how Japanese women's rights are annihilated and her presence is ignored, is to be analyzed through the liberal feminist perspective. It seeks for equal rights for women and men, believing that individuals should be treated in accordance with their talents and effort etc., as opposed to characteristics of their sex. They campaign to remove any obstacles, political, social, or legal, to realize women as having the same opportunities like their male counterparts.

This study, therefore, tries to explore how the female character of The Scent of Sake experiences gender inequality in the form of stereotype, discover its dreadful effects upon her, and identify her struggle to eliminate the typecast. As reflected in the title, this study analyzes Rie's Gender Stereotype in Joyce Lebra's"The Scent of Sake" through liberal feminist literary criticism.

\section{LITERATURE REVIEW}

\section{a. Stereotype}

Stereotyping refers to the act of "judging someone on the basis of one's perception of the group to which that person belongs"[4]. It is "the unconscious or conscious application of (in) accurate knowledge of a group in judging a member of the group" [5]. Stereotype is basically a view applied to a group of individuals[10] involving "overgeneralizations" of characteristics to large human groups[7].

Johnson and Redmond[8] explains that "stereotype arises when we assume that an individual will have particular norms, values and modes of behavior because of some features, such as color, race, nationality, education or upbringing. "Their explanation implies that stereotype is mainly caused by people's simplifying the world through categorization. People use categorization to simplify and cope with the large volumes of information to which they are continually exposed. They often use visible characteristics, such as race, gender, and age to categorize others[7].
Stapel and Noordewier[9] use the concept of 'system justification theory' to explain in which situations people are likely to use stereotypes. System justification theory purports that people stereotype to justify the social system, which is the social structure they are a part of. According to this theory, people use stereotype to maintain their belief in a just world and to rationalize the status quo. People use stereotypes, they also explain why some groups of people get so little, while others get so much. Put differently, people do so because stereotypes are handy tools that allow them to blame society's victims (poor people are just lazy) and it idolize its winners (rich people simply work hard. They conclude that stereotypes help people to categorize the social world and thus induce structure.

Stereotypes are ubiquitous, meaning they are ever-present [6]. As such, many types of stereotypes exist, including age, race, ethnic, self-stereotype, and gender, amongst others.

\section{b. Gender Stereotype}

The totality of fixed ideas about the natural extermination of male and female social characteristics can be described as gender stereotyping[11]. A definition of gender stereotypes involves schematically generalized, simplified, and emotionally colored images of femininity and masculinity.

Kliuchko[11] further highlights other important features of gender stereotypes. The attribution of qualities according to masculinity and femininity tends to individuals. Characteristics such as "ActiveCreative" are attributed to masculinity, including activity, dominance, self-confidence, aggressiveness, logical thinking, and leadership ability. "PassiveReproductive" principles are attributed to femininity with characteristics such as dependence, solicitude, anxiety, low self-esteem, and the emotionality associated with it.

Gender stereotyping, which is also referred to as 'sex-role' stereotyping, has been 'consistently identified as a psychological barrier to women's advancement in the workplace"'[12]. One of the reasons for this is that gender stereotypes tend to be associated with certain family and professional roles. They prescribe that women should be like and how men should behave.

"For a woman, housewife and mother are considered the most significant social roles. She is assigned to the private sphere of life: home, giving birth to children and responsibility for interrelations in 
the family are entrusted to her. Inclusion in social life, professional success, and bread winning are mostly men"[11].

\section{c. Generic Gender Stereotype}

According to Selamolela[13] in his research Causes of Gender Stereotypes in Workplace, the workplace abounds with gender stereotypes that can impact women negatively. This illustrates the most common gender stereotypes found in the workplace. The first four gender stereotypes discussed below are generic gender stereotypes about women, their abilities, and attributes; meanwhile, the subsequent three focus on the leadership element in a workplace that involves gender stereotyping.

1. Women are Emotionally Unstable, Weak, and Timid

Ridgeway[14] reports that women are considered lack the assertive ability and the leadership skills which are crucial when they are interacting with others. She argues that the gender system is deeply associated with leadership and social hierarchy because gender stereotypes contain status beliefs that associate greater status worthiness and competence with men than women, who are psychologically unbalanced, pathetic, and fearful.

2. Women are Risk Averse

A common perception about women in the business world is that they are risk-averse[15]. He argues that women continue to be perceived as riskaverse because of three factors: their risk taking is unrecognized, they mitigate costs when taking risks, and their engagement in role-congruent behavior leads to the perception that they are risk averse. This therefore means that the perception upon women as a risk-averse profile is not entirely true; they embrace risk but the perception is perpetuated by some behaviors displayed by women in the workplace, which are then interpreted as being risk averse.

\section{Women are Intuitive Decision Makers}

Women managers are seen to embody what are perceived to be the emotional, illogical, and sexual aspects of organizations, compared with men who tend to symbolize gender-neutral rationality and decision making[16]. Furthermore, Gilbert[17] in a study conducted in three English speaking countries (America, Jamaica, and Australia) examines the differences between female and male business professionals. The finding is that there indeed exist notable or significant differences between the work preferences of female and male business professionals within different countries.

\section{Angger is not Feminine}

Brescoll and Uhlmann[18] argue that displays of certain emotions such as anger can communicate that an individual is competent and is entitled to high social status. However "women who do not display womanly attributes and men who do not display manly attributes are judged less psychologically healthy and they are evaluated less favourably than those who do (Heilman, 2001). Females who express anger break this feminine norm and therefore may not experience the boost in status enjoyed by angry men.

They propose that for men, expressing anger may heighten status: men who express anger in a professional context are generally conferred higher status than men who express sadness. On the contrary, for women, expressing anger has the opposite effect: women who express anger are consistently accorded for being lower status and lower wages, and they are seen as less competent than emotional men and unemotional women.

\section{Think Manager, Think Man}

One of the most obvious gender labels is a "male as manager" stereotype, which fosters bias against women in managerial selection, placement, promotion, and training decisions[1]. Boyson and Nkomo[19] argue that it is important to study the perceptions individuals hold in regards to the stereotype. When we think manager, we think male. The importance of women for managerial activities in all countries has been thought to be the persistent stereotype that associates management with being male[1].

\section{Leadership is the Masculine Job}

Carli and Eagly[20] assert that "leadership has traditionally been construed as a masculine enterprise with special challenges and pitfalls for women." Another similar perception is that successful managers are aggressive, forceful, competitive, self-confident, independent, and have a high need for control, which fundamentally contrast from the commonly held perception that women lack these qualities and are characterized as being relatively submissive, nurturing, warm, and selfless[21]. Such a classification of leadership, which is based on masculine terms, relegates everything socially perceived as 'nonmasculine' to the marginal and places it primarily 
outside the organization. It makes harder for women to be recruited and function in managerial jobs.

7. Communal attributes have no place in leadership

In understanding leadership attributes, Eagly[22] lists agented (achievement orientation traits) and communal attributes as particularly relevant in understanding the leadership aspects of gender roles. They describe agented characteristics, which are ascribed more strongly to men than women, as primarily assertive, controlling and confident - for example, aggressive, ambitious, dominant, independent, daring, self-confident and competitive. In employment settings, speaking assertively maybe included as agented behaviours, competing for attention, influencing others, and making problemfocused suggestions.

Communal characteristics describe a concern with the welfare of other people, for example, affectionate, helpful, kind, sympathetic, interpersonally sensitive, nurturing, and gently. In employment settings, speaking is might be seen as communal behaviours, not drawing attention to oneself, accepting others' direction, supporting others, and contributing to the solution of relational and interpersonal problems. These attributes displayed by women are viewed in a generally negative light as contrary to what business leaders should be like.

\section{METHODOLOGY}

This study focuses on gender stereotype which is experienced by Rie as the main character in The Scent of Sake novel by Joyce Lebra produced in 2009. It contains 383 pages and 45 chapters. The researcher read all content of the novel, observed the issue reflected in it, filter the content into the data, and categorized and analyzed the data. The researcher analyzed the data through liberal feminism.

\section{RESULT AND DISCUSSION}

Rie is the main character of Joyce Lebra's The Scent of Sake. In this novel which portrayed the era of $19^{\text {th }}$ century showed many perspectives on negative point of view toward women, all it is called gender stereotyped.

\section{A. Gender Stereotype Experienced by Rie}

1. Think Manager, Think Men
The first form of gender stereotype depicted in the novel is that being a manager is male's job. When people talk about managerial activities, they think about manhood/male's work. This is evidence in Lebra's The Scent of Sake.

Regarding the sake business management of Omura family, Jihei made a firm statement when coming to Rie's house for the first time,

"Kin is the chief clerk and manager of the entire

White Tiger operation.” (p.21)

The statement entails that he is the manager of the overall business; therefore, he is the one with whom everybody discusses and consults: "He was consulted in any major decision" (p.21). Thus, women have no considerable position in both the current and the prospective of sake business.

Regardless the qualification, the manager position for the business after Kin is to be automatically held by Rie's husband because he is the man of the family. Kinzaemon said,

"This is Jihei Okamoto, Rie's new husband and my

successor. Now we have a man to succeed me."

(p.21)

The statements indicate that the prospective manager for the sake business is Jihei. He is appointed because of his sexual identity as a man (Rie's husband), not because of his skill and competence.

Despite familial status of Rie as Omura's daughter who is in charge of the house work and responsible for upholding the family stuffs, she has to obey her father's decision appointing her husband as the manager to run the sake business. It seems that Rie, due to her sexual identity as a female, has no chance to become the manager of her own family's business. Rie's father said,

"Rie, the future of the Omura House, rests with you.

You alone are the one who will maintain the honour and prosperity of the house. Remember, this is a beavy responsibility." (p.2)

The above statements indicate that women in the novel -as represented by Rie could not, are not allowed to, and are considered incapable to become the manager of sake business. This prejudice is blindly applied to Rie, the only daughter of Omura family. In 
spite of assigning her own daughter as the manager, her father prefers to adopt a son, who afterwards becomes her husband, to maintain the honor and the prosperity of the house. Her father indirectly prejudges that males are more capable of being the manager than females in any condition. He considers Rie (and probably all Japanese women) as lack of managerial proficiency - a true image of "Think Manager Think Male" stereotype.

2. Communal attributes have no place in leadership This novel exemplifies how the communal attributes have no place in leadership. Women as house wife should work at home with loads of house work. The subsequent statement of Rie toward Tama, her daughter, supports the above premise:

"The workers are your primary responsibility, both the kitchen workers and the Kurabito. You need to see that they are well fed and clothed and cared for when they are ill. Without them we could not maintain the reputation of White Tiger." (p.211)

It kinds of cultural reproductions, because Rie felt it in her life then she does the same thing to her daughter. It is unambiguous that "to make sure the workers are well-fed and clothed and cared" (which are classified as communal attributes in sake business) is the primary duty of women. A woman is also in charge of other communal-based activities, such as food, house, clothes, etc. as Hana (Rie's mother) speaks to Rie in the first time when Rie will have a marriage.

"A brewer's wife was responsible for the food, housing, clothing, health, and wellbeing of all the brewery workers." (p. 5)

That is why whatever the daughter will be does not really matter. Whether or not a girl is smart makes no difference for the family.

"Still, with a danghter, intelligent or not, you bad a range of choices for an adopted husband for her."

The statement above indicates a stereotype faced by a woman or daughter because she will never be a leader in the business. It does not matter how that girl is. A range of choices for an adopted husband means that the daughter will never have their own choices for their life couple.

The woman is stereotyped as having no power to choose her husband by herself because the mere duty of women concerns with welfare of other people, especially their parents, who arrange the husband for them.

Particularly, women who carry out housework like clothing, cleaning, and cooking are regarded as having communal attributes. These are different from the agented characteristics of men who are, in employment settings, competing for attention, influencing others, and making problem-focused suggestions. That is why women or brewer's wives here do not have any position in the business because they stereotype that communal attributes have no place in leadership.

3. Woman are intuitive decision makers

In business, people are supposed to have brilliant ideas in making decision. Good leaders are always related to rational, not intuitive, decision makers. Following this justification, women are not projected to be business leaders because they are stereotyped as intuitive decision makers. The example is shown in the reminder of Rie's mother toward her daughter:

"I'm afraid this may be the result of your constant

involvement in the affairs of the house." (p.44)

Rie'shidden-yet-frequent involvement in sake business, despite the ban from the family and tradition, is considered to cause intimidation toward Jihei,

"Maybe you are intimidating Jibei." (p. 44)

Although Rieis interested in business very much, she should not follow her intuition to make decision in the house and, in turn, make Jihei feel uncomfortable. Her mother said,

"...often feels a stranger in his new home." (p. 44)

Since Jihei seldom stays at home and prefers going to Geisha's house at night, the mother suggests Rie,

"Maybe you should leave any advice to Father and

Kin. It may be difficult for Jihei to accept suggestions

from a woman." (p.44)

Rie's intuition to give advice to her father,Kin, and Jiheiwill likely influence Jiheiteh the business management. It is difficult for men to accept 
suggestions given by a woman because she is recurrently portrayed as irrational decision makers who follow the intuition(emotion) more than the cognition (intelligence). Maybe Rie does not make any mistake related to the sake business, but she is stereotyped as an intuitive decision maker who is not capable of being a good leader / manager.

\section{B. The Effect of Gender Stereotype}

\section{Woman marginalization in management}

Women are negatively stereotyped weaker and more inferior than men; therefore, they have little chance to get a job especially in sake business. Rie is the heirs of Omura family but she could not do anything in relation to the business advancement. Being manager is male's responsibility and leadership is men's job. The woman is in charge of the house work "only" so that she struggles by herself, not by the structural support, to have a position in her own family's sake business.

In the first chapter of the novel, women are stereotyped as someone (or, something) that can decrease the quality of the Sake: "Let a woman enter the brewery and the sake will sour" (p.1). Furthermore, everyone in Nada agrees that sake production is men's business, no place for women: "Everyone knew that sake brewing was a man's world ...” (p.2). Women, especially those of brewer's wife, are given a load of domestic work at home, such as washing the dishes, cooking, and cleaning. This is stated in the statement below:

"A brewer's wife was responsible for the food,

housing, clothing, health, and wellbeing of all the

brewery workers." (p.5)

The stereotype has disadvantaged women as the inferior group to men in economic aspect because women cannot (or are not given opportunity to) do anything in sake business. As a result, women are considered incapable of becoming the leader and portrayed as less independent. Throughout the novel, it is true that there is marginalization of women because of gender stereotype. Women has very little this is to say, no- chance of getting success since the society has constructed a common belief and transferred from generation to generation that all kinds of major jobs are for men only.
2. Women marginalization in educational access.

One of the most apparent domino effects of women's annihilation in business field is that they are constantly regarded not deserving (quality) education. Women, even of brewing family, are supposed to acquire such "feminine" skills as knitting, sewing, cleaning, and cooking. Literacy skills such as reading and writing are neither very common nor important for women to obtain. This situation indirectly leads women to have very limited access to participate in advancing the business.

"She was proud that she could write and use the abacus, skills not common to every woman in brewing

families." (p.86)

The novel illustrates that women do not need to have high education and competence because they have been stereotyped as unable to working and handling the business. Rie herself should learn autonomously to understand the management of the Sake business. She wants to proof that she is equal to men in some cases, especially in giving the solution related to the business.

4. Women's lack of decision making in marriage.

Another effect, which is quite imperceptible, of gender stereotype in sake business faced by Rie is that she cannot be herself, the real Rie. There are a number of examples showing how Rie should bury her wish because of the gender stereotype. First of all, she could not be a good daughter for her father because her father dreams of a son to carry on the family business, to help him create the dynasty that he has envisioned long time ago. This occurs because she is the daughter, not the son, of the family

"Always he'd dreamed of a son to carry on the family business, to help him create the dynasty that he'd envisioned long ago." (p.21)

The dream of the father is supposed to come true, not because of the real accomplishment and effort but due to the presence of a male child. It is believed that the business can improve well and become the first sake in Nada if a man handles the managerial position. In contrast, when a woman comes, the dream related to the sake business will never come true. It is 
prejudged that women are not able to run the business and can bring it to failure.

Second, Rie cannot marry with a man that she really loves because of the tradition in sake business and the stereotype on woman's restricted role in mate selection. Her mother said, "Personal feelings have so little to do with marriage" (p.7). Rie has ignored her personal feeling in marriage, as she thinks that the man is "Not as handsome as the Kato's third son" (p.6). The stereotype that her family upholds is that Rie should get married to the man of the same trading background to guarantee the successful prospect of the family's sake business in the future. This is strongly maintained by the family because women are stereotyped as incapable of running the business and thus the family should adopt the husband for her from another sake business.

"The selection of a spouse for the head of the house would inevitably affect the business and the welfare of the entire house." (p.183)

Because of the gender stereotype in sake business tradition, Rie has to spend the rest of her life with a strange man she has never known before, and she has to conceal her feeling to another man that she loves.

"You are close to twenty now, and it's high time we were serious about your marriage. And we have several good candidates. Your father and I are especially interested in the Okamoto son, Jibei. He has been apprenticed to the Ohara house, so we know he has had excellent training, and the reports we hear are good." (p.6)

Different from Rie who is negatively prejudged, the son from Ohara House is stereotyped as a good man who has excellent training experiences, and it is the report that the family hear from the public. Males are stereotyped as good at business management, but females are stereotyped as bad or incapable of doing any kinds of business.

Third, Rie has to bring a geisha's son to the House, which is actually resulted from dishonesty of Jihei. The common stereotype in Japanese culture is that a wife of sake business man must deliver a baby son to be the heirs of family. However, because of not being pregnant, Rei is demanded to do something that she actually does not want, i.e. take caring of the geisha's son. To affirm her own thoughts, her mother said,

"If you don't become pregnant soon we may have to bring the child into the house, especially if it's a boy."

(p.45)

It is, of course, very hard for Rie to approve the fact that her husband has an affair with another woman, and that woman is a geisha. Moreover, by stereotype, she is required to take care of geisha and her husband's son in her own house during her life time.

All things considered, gender stereotypes have given bad effects to Rie in her life. Due to the negative label, Rie -and other Japanese women- are annihilated in many aspects: economy, education, and social life.

\section{Struggling}

\section{Rie's Struggle: Reversing the Stereotypes}

First of all, whatever the daughter will be does not really matter. Whether or not a girl is smart makes no difference for the family.

"Still, with a daughter, intelligent or not, you had a range of choices for an adopted husband for her."

(p.3)

The statement above indicates a stereotype faced by a woman or daughter because she will never be a leader in the business. It does not matter how that girl is. However, Rie sure that she can be more intelligent than her husband or another man in her family or in her father's Sake business. She is interested in sake business since childhood then she has a dream that she can make her sake business become the first sake business in Nada as her father always says it. Rie always think a lot for her sake business and she has many ideas related about sake business. She often transfers her idea to Kin because she knows that woman's voice is does not needed in the business. But Rie sure that one day because of her idea her sake business become success and woman's voice is needed. That is why first thing that she can do for sake business is by transferring her idea to make better the business through Kin.

'Wouldn't this be a good time, then, to expand our shipments to Edo, to try to sell, say another twenty 
percent in that growing market? Can't we take advantage of it and recover the ten percent of our market we lost to Yamaguchi?” Rie stopped to look intently at Kin.

Rie inhaled her favorit yeasty aroma and waited. Would he listen to the merits of her idea or dismiss what she said just because she was a woman, or because be knew her father didn't want her intruding in business decisions? She kept her eyes on Kin's face. Come on, come on. Agree!

"Well, then, all right. I'll try." He rubbed his face.

(p.25)

The above data illustrate that Kin does not directly agree with Rie's opinion, because Rie is a woman. In addition, presenting such an idea to Rie's father and husband is too hard because they stereotype women as inferior group in business. Through long debate about the sake business, Rie can convince Kin to consider her idea related to the sake sales.

Another datum confirming that Rie contributes a lot of brilliant ideas for the betterment of sake production is noticeable during serious talk about different tastes of sake produced by another house although woman stereotype that she does not able in business management. Rie presents that the taste of sake is different because of different amount of the added water. Therefore, Rie suggest them be the owner of water and sell it. Rie feels certain with her idea because the water is believed to improve the quality of sake.

"Aren't we moving too fast?" Jibei protested again.

Rie sighed again, louder this time. "Not to move

tomorrow would be too slow. We'd lose our

advantage." (p.146)

In short, it is kind of reversing the stereotypes toward women. Rie has proven that she is responsible for any of the assigned duties, and that she struggles against the stereotype.

However, Rie never feels hopeless. She transfers her idea to Kin. She wants to expand shipments to Edo, try to improve the sales up to twenty percent, etc. Rie is always excited to improve the business through her ideas.

'Wouldn't this be a good time, then, to expand our shipments to Edo, to try to sell, say another twenty percent in that growing market? Can't we take advantage of it and recover the ten percent of our market we lost to Yamaguchi?" Rie stopped to look intently at Kin. (p. 25)

Although Kin claims that the idea is of his own, Rie never complains. She is happy because her idea is promoted to increase the business. After her first idea about expanding the shipments to Edo has been successfully implemented, she proposes another idea for the business. She said to Kin, "They will help White Tiger, I'm certain." (p.58). Her sound statement "certain" shows that she feels energized in her involvement to the business.

In transferring Rie's idea or opinion shows that Rie is actually more superior to Jihei, in terms of business innovation. As Jihei does nothing for the sake business advancement, he in fact demonstrates his lack of competence in leadership and management. For example, when the business is encountering failure and prone to lose customers, Jihei could not do and decide anything. Quite the opposite, Rie proposes some ideas and criticizes Jihei's futility.

"What do you suggest?" Jihei wondered.

"Did the head of the house have no ideas of his own?

Disgraceful." Rie's thinking.

"Why not?" Rie asked. "Who would object?

Shogunal commissioners like White Tiger as well as

anyone." Yoshi looked back and forth from Rie to

Kinno with his mouth open. (p. 157-158)

On the next scheme, women are occasionally characterized as more superior to men in terms of courage in making decision and bravery in doing the right things.

Reversing the stereotypes is the first strategy carried by Hall in his book Representation: Cultural Representations and Signifying Practices, then Rie's struggle also appropriate with Wollstonecraft's idea on liberal feminism in reversing the stereotypes that women should not be inferior to men, women should not (be) associate(d) with hypersensitivity, extreme narcissism, and excessive self-indulgence.

Rie is characterized as a woman struggling to be independent. Many evidences are found in her opinion stated or attitudes acted. Although the old tradition says, "Let a woman enter the brewery and the sake will sour" 
(p.2), Rie always tries to learn anything related to sake. She often plays near the brewery to know the production steps of sake: "She had always played near the door and the barrels as a child" (p.3).

After listening to the stigma that a woman entering the brewery can make the sake become sour, Rie feels very worried as she "...waited, terrified, for the news that the sake had soured." (p.2). However, "It never bad." (p.3) means that the sake never turns sour although she commonly plays near the brewery.

One day, another family finds their sake sour, as told by Rie's mother,

"But you know the Ikedas lost their whole cellar last year when the sake went sour." (p.6)

Because of the case, Rie anxiously strives to prove whether it is true or it is only a tradition maintained from time to time. Rie, then, struggles to search for the reality by playing near the brewery.

Although Rie does not posit the central position in the sake business, she always comes with brilliant ideas and solutions when the trouble comes. She steps across the manager and head of the house, Kin and Jihei. Rie believes that she can keep the honour of Omura's sake business. For instance, when White Tiger need an idea in response to a situation in which selling the sake of small brewers under their own label is not enough and another sake business in Nada is moving into their market, Rie firmly states, "We must look elsewhere. We need something new." (p.160). Then, Rie tries to offer a solution:

"...I propose that we buy his brewery, his kura, and sell it at a higher price." (p.160)

Listening to Rie's opinion, Kin replies, "A new idea. Interesting. It might work.” (p.160). Influenced by prejudice, Jihei only frowns and objects Rie's idea, judging that Rie is "...always pusbing to be first in everytbing" (p.161). The statement designates Jihei's awareness that Rie always wants to be the first in the business. Rie said,

"We bave to be always on the lookout for something new as well as trying to improve our quality." (p.161)

Rie's ambition here indirectly rejectsthe stereotype that women have communal attributes and that the ambition is men. Rie ultimately eliminates such a stigma, showing that she is more ambitious than Jihei, her own husband and the head of Omura family. From those evidences shows the same opinion of Wollstonecraft that women must be independent.

Not only women must be independent but here also appropriate with Wollstonecraft's idea that women should not be inferior to men. Since childhood, Rie knows that she could not join the business. She really knows the appropriate place for woman, i.e. in the kitchen, as what her father commonly said, "The kitchen. That was the place of women." (p.3). The word "women" (in plural forms) means that the kitchen activities are not only for Rie but also for Japanese women in general. Rie herself, however, is interested in business and she wants to work for the business.

"Here she would work for the house, do ber best for

White Tiger and for her father." (p.19)

Rie's enthusiasm to work hard and do her best for her father indicates that the Omura's business is related merely to males, not to females (like mother or daughter). This strengthens the notion that business in Japan is not for women, and Rie is obliquely rejected.

At first, Rie does not know how to make her dreams come true. It is mentioned in the novel that,

"Just how she would accomplish this she was not sure.

But she would do it." (p.19)

Nevertheless, as the time goes, her motivation to avoid being "a girl in a box" becomes stronger and she does not want to be too submissive to the unfair rule / tradition. Later, she tries to open her father's eyes that she is capable of doing the business and that she is indispensable to the business, saying:

"Kinzaemon would come to know that she was indispensable to the business, far more than "a girl in a box." (p. 19)

Rie always thinks a lot about her family's business. She is eager to create brilliant ideas that can increase the business profit. When she cannot directly communicate her idea to her father, she does a negotiation to Kin.

"You know it's difficult for me to speak with Father of any business matter." Then Kin answered "Yes, 
it seems so, doesn't it? Well, you know, most men in

Nada don't want women entering the business side or handling cash.” (p.25)

That men and women are portrayed differently in the conversation shows the existence of stereotype applied not only to Rie but also to all women involving in sake business. However, Rie never feels hopeless. She transfers her idea to Kin. She wants to expand shipments to Edo, try to improve the sales up to twenty percent, etc.

In brief, women are not (and should not be) inferior to the other sex. If they are given an opportunity, access, education, and training, they can even be superior -or at least in the equal position- to men. And, Rie has clearly depicted such characteristics.

Besides on stereotype toward women in sake business, but being a daughter in sake business, the family will never put the same faith as a son:

"Although her father loved her, she knew he didn't

put the same faith in her as he would have in a son."

Rie knows the gender prejudice and discrimination put upon her and other Japanese women, especially in sake business. However, she promises to make her father proud of her:

"...she had promised herself that one day she would

make her father proud.” (p.24)

Rie spends her time to learn secretly many things related to sake business. She often listens to what the men are talking about the business. She watches and learns what she might act in the future, as stated below:

"For years she'd been watching and listening in silence, learning so that one day she could act." (p.24).

Rie is characterized as a woman who does not possess such stigmatized "feminine characteristics" as hypersensitivity, extreme narcissism, and excessive self-indulgence. Although the father does not put the same faith in her as he would have in a son, she has promised to herself that one day she would make her father proud of her competence. Rie's interest in business also shows that she is not self-indulgence.
Regardless her awareness upon the father's not putting the same faith because of her sexual identity, Rie still wants to make her father's dream come true. Instead of hypersensitivity, Rie shows that she is an ambitious and reasonable daughter so that she is willingly - not selfishly- prepared to work in any division of the business.

A woman associated with hypersensitivity, extreme narcissism, and excessive self-indulgence would not pay attention to business or to a field beyond their concern, just like the stereotype applied in Sake business. Rie, however, has shown that not all women possess hypersensitivity, extreme narcissism, and excessive self-indulgence. She herself works very hard to struggle against gender stereotype, as illustrated in the following quotation:

Hard work seemed the best antidote to the outrage she felt at the illegitimate infant Jibei had brought into the house. She felt energized, determined to somehow redress this betrayal. (p. 56)

In short, not all women can be associated as with hypersensitivity, extreme narcissism, and excessive self-indulgence. Rie has proven that she is responsible for any of the assigned duties, and that she struggles against the stereotype.

Finally, from all data the writer conclude that this novel uses the first strategy of Hall by reversing the stereotypes through Rie by transferring her brilliant idea for sake business. The second strategy will explain in the next discussion.

\section{Rie's Struggle: Substituting the Stereotypes}

The second strategy is substituting the stereotypes. Women in sake business have no responsibility related the business, their responsibility are giving a food, cleaning the clothes, sewing the clothes, the healthy, the important is not related about any business. As her mother always says when Rie played near the brewery. "A brewer's wife was responsible for the food, housing, clothing, bealth, and wellbeing of all the brewery workers." (p.5) another stereotype for women is it does not matter how is she, is she smart or not because in the end of the marriage the parents will adopted for her a mukoyoshi or husband for succession sake business. 
The most complex evidence showing women is able to do the substitution of men's place, it is Yoshi's wife who becomes head of the house to succeed Omura's family business. The following quotations show how women are independent sex.

"You know we cannot exist without a successor to Yoshi."

'I have decided because of Hirokichi's stubborn opposition to have you succeed for the three years allowed."

Tama's eyes widened. "Is it possible for a woman?"

Rie smiled. "Yes, with the approval of the local officials a woman can succeed for three years. It's in the regulations of the association, though it doesn't often happen." (p. 338)

In conclusion, Rie is characterized as an independent woman due to her excellent ideas and solutions related to sake business. If women have the same right as men, people can see their capability fairly. The above passages have shown that women can also be very independent / self-sufficient. Men should not stereotype women before knowing their competence.

The independence of Rie is also evident when Yoshi, her first son who replaces the position of Jihei, asks her to transfer the seal for affixing the document, saying "...I'm house head now. I need the seal for official business." (p.202). Rie, however, does not transfer it because the seal is the most crucial thing in Sake business, including its future. Rie said,

"I have made final decisions since my father died, and

I will continue to do so."

Then Rie's struggle also appropriate with Wollstonecraft's idea on liberal feminism in reversing the stereotypes that women should not be perceived as an object or a property.

It is stated in the novel that:

"...the marriage was the culmination of a successful negotiation to ensure the future of the house. But for

Rie it felt like a death sentence." (p.16)

To ensure the future of Omura family indeed lies on the hands of their children. As the son dies, they only have a daughter. Therefore, they adopt a husband from another sake business and design a marriage with their daughter to ensure the future of the business. The reason for adopting a son is the stereotype that woman is "only" a property for a business to be owned by a prospective leader (man).

The researcher considers that woman in this context is seen as an object and property to be owned by a husband from another sake business to ensure the future of the house. Rie is not able to refuse the tradition because it is the most important thing for the family, but Rie struggles by herself to realize what she wants to be.

Rie thinks that getting married to a man that she does not love is a bad thing. But her father always says about the marriage, and she feels that her father's words are like "death sentence." On the other hand, she does not focus on the marriage so that she is no longer treated as an object in the business anymore. She struggles by herself for what she wants to do, not depending to another person like her husband. This affirms the postulate that Rie has strong willingness.

Rie spent less time on the business of the brewery, but

after two months she began to take part of each day

to attend to matters in the office and new storeroom.

(p. 107)

Rie rejects the stereotype that women are intuitive decision makers because Rie can successfully become good, wise decision makers:

"Planning and decision making were done by Rie and Kinnosuke with Yoshitaro..." (p.167)

Jihei, the Head of Omura, does not do anything on his own initiative; planning and decision making are carried out by Rie, Kinnosuke, and Yoshitaro, as shown in the following quotation:

"Tihei was becoming increasingly ineffectual as head of the house. He seldom did anything on his own initiative." (p.167)

Throughout the novel, Rie is portrayed as a character struggling against the stigma "women as an object or property" because she is able to do many things as what men are, especially in business area. Sometimes she is even described as more superior than Jihei, the manager of her family's business and her "adopted" husband. Although Rie is woman who 
stereotyped capable in doing any business but she shows that she is more competence than her husband.

Furthermore, in education sector, Rie has to be smart as men. Education is a medium to guide people and make them smart. When men and women have an equal education, they might have the same intelligence. In the novel, women are described as lack of knowledge about sake business. Facing this disadvantaging situation, Rie struggles by her own way to get an equal education to the men. The following quotations show Rie's way.

She tried to remember everything Kin said. "In this ledger here you see all our suppliers of Yamada

Nishiki rice, Kojimold, and yeast. And in this one here are all our major customers." As Kin talked, Rie heard the shoji to the outer office open and the men's voices grow fainter. (p. 22)

Rie pays attention to everything related to sake production, particularly when Kin is talking to Jihei about the main suppliers and customers. Everything about business, such as sales route and account book, is forbidden for women to know. The example of this is the mother's anger toward Rie because she catches the daughter over an account book in the office:

"You know that's not really your responsibility, Rie.

Father and Kin may be annoyed if they discover the ledger missing from the office." (p. 42)

The phrase 'may be' in the conversation is used because of the stereotype, i.e. thatany women is not allowed to interfere the sake office. Bu Rie tries hard to convince her mother that everything will be okay if she knows little about the cash of sake business. She said:

"Mother, I always keep track of accounts now. Kin realizes that I need to know where we stand. And he says our finances have improved since I have been following them and making suggestions. Father doesn't need to know." She smiled proudly. (p. 42)

The utterance Father doesn't need to know' here shows that it is a kind of silent / soft struggle of Rie performed through negotiation with Kin and her mother. Rie's statemen t, "Kin realizes that I need to know where we stand,"signifies that she is more interested to know anything about sake business. Besides, she also endeavours to have an equal education in writing and using the abacus, which is not a common skill for women in brewing families.

"She was proud that she could write and use the abacus, skills not common to every woman in brewing families.” (p. 86)

Brewing families here means the family owning sake business, and the phrase 'every woman' means that the stereotype is applied to all women. But Rie as a woman of brewing family has those skills.

The next datum shows that Rie has those skills secretly. She often learns to write although she is aware that it is not her great skill. She shows high spirit to do it voluntarily:

".... She went back to the secret drawer, took out a few more coins, and placed them in another small silk. pouch."

"She knew her calligraphy was not highly skilled, but she carefully wrote a few lines on the best rice paper, folded the note, sealed it with wax, and thrust it into her sleeve." (p.86)

The above passage indicates that education at that time, especially in sake business, is considered important but for males only. Rie struggles against the stereotype and tries to reach an equal education.

From those analyses, the writer uses Hall's strategies in doing analysis on Rie's struggle against gender stereotype with the concept of Mary Wollstonecraft in liberal feminism. The researcher concludes that The Scent of Sake by Joyce Lebra uses two strategies in struggling against gender stereotype they are reversing the stereotypes and substituting the stereotypes through Rie as the main character. Although it does not erase the stereotypes but Rie in this novel can show that woman is not always more inferior to man, and she can do what man do in any aspect especially in sake business aspect.

In general, this second strategy more brave than the first strategy, Rie breaks some rule such as she has sempoa skill that not common for women in Nada, because that skill just for who will know about business and it is man. The next she wants Tama to be a head of Omura, because she sees Tama's competence, and she brings the seal of sake business means that all decisions depend on Rie. However, 
these strategies cannot break the stereotypes but Rie can show that the stereotype is not exactly right.

\section{CONCLUSION}

Joyce Lebra'sThe Scent of Sake portrays some issues on Japanese gender stereotype through Rie based on the finding and discussion in previous part, the female major character, who struggles against the stereotype in her family's sake business. There are some sorts of gender stereotype applied in such traditional commerce.

The first stereotype is "think manager, think male", which is obvious in the domination of males (Rie's father, Kin, Rie's husband, and Kinno) in the central managerial position. The second one is a "leadership is a masculine job" rule by which men are given leadership jobs in sake business and women are assigned to wash the barrels. The third is that "communal attributes have no place in leadership" and, therefore, women are conditioned to work in the kitchen only: for cooking, cleaning, sewing, and weaving.

The other kinds of stereotype are that "women are emotionally unstable, weak, and timid," that "women are intuitive decision makers," that "women are risk averse," and that "anger is not feminine." These labels have in all situations disadvantaged women not only in the workplace but also in daily activities. Therefore, Japanese women -as represented by Rie- are supposed incapable of working hard or being a leader.

The effects of gender stereotype toward women, especially Rie, are apparent in three sectors: economy, education, and social life. In economic aspect, women have little access to run or to participate in a business. Rie should find her own way to enter the business although she is the daughter of the owner and is capable of handling some business activities. In education, the chance for women to get essential skills is very limited. They are not supposed to acquire adequate knowledge related to the sake business. In social life, a woman like Rie cannot be herself in marriage as she is supposed to be the wife of the adopted husband and tolie in an inferior position toward her husband.

To reduce the negative effects of gender stereotype in her family and society, Rie struggles against the situation through such attempts as negotiation, cooperation, and rule / tradition breaking. The purposes of her struggle is to eliminate the stigma addressed to the Japanese women and prove the real qualities of women -as proposed by Wollstonecraft in her Theory of Liberal Feminism.

Rie can successfully shows that women are independent. Although women in Nada are stereotyped as incapable of doing a business, Rie could propose brilliant strategies and ideas for the business advancement and she can actively participate, yet secretly, in the management activities. Rie also depicts a profile of woman who is not associated with hypersensitivity, extreme narcissism, and excessive self-indulgence. She struggles to achieve an equal education and competence. Rie has proven that she knows about sake business and that she does the business activities well while others might be incapable of doing so.

Through considerable struggles, Rie has proven that woman should not be viewed as inferior to man. That men are always superior to women is not applicable to Rie's profile. She can be more superior in terms of business innovation ideas than Jihei, her own husband, and the head of Omura House. Rie also effectively confirms that women should not be perceived as objects or properties. Rie herself has tried very hard to play an active role as a subject in her own family's business of sake production.

\section{REFERENCES}

[1] Schein, V. 2007. Women in Management: reflection and projection. Women in Management Review.

[2] Hendry, J. 2003. Understanding Japanese Society, New York, Routledge.

[3] Shinotsuka, E. 1995.jyoseigahatarakusyakai (Working women's society), Tokyo, Keisousyobou.

[4] Robbins, S. P., \& Judge T. A. 2007. Organizational Behaviour, New Jersey: Pearson Education Inc.

[5] Agars, M. D. 2004. Reconsidering the Impact of Gender Stereotypes on the advancement of women organization. Psychology of Women Quartely.

[6] Boyson, G. A., Fisher, M., Dejesus, M., Vogel, D., L., \& Madon, S. 2011. The mental health stereotype about gay men: the relation between gay men self-stereotype and stereotypes about heterosexual women and lesbians. Journal of social and clinical psychology.

[7] Bell, M. P. 2007. Diversity in Organizations, United States of America: Thompson South-Western.

[8] Johnson, R., \& Redmond, D. 2000. Diversity Incorporated: Managing people for Success in a diverse world. London: Pearson Education Limited. 
[9] Stapel, D. A., \&Noordewier, M. K. 2011. The Mental roots of system Justification: system threat, need for structure, and stereotyping. Social cognition.

[10] Boyson. 2010.Gender Role Stereotypes and Requisite Management Characteristics: the Case of South Africa.

[11] Kliuchko, O., I. 2011. Gender Stereotyping in Studying Pressing Social Problem. Russian Social Science Review.

[12] Fullagar, C. J. 2003. Managerial Sex Role Stereotyping. International Journal of Cross Cultural Management.

[13] Selamolela, K., C. 2011. Causes of Gender Stereotype in Workplace. University of Pretoria.

[14] Ridgeway, C. L. 2001.Gender, Status \& Leadership, journal of Social Issues.

[15] Maxfield, S. 2010. Gender and Risk: women, risk taking and risk aversion. Gender in Management: An International Journal.

[16] Green, E., \& Casell, C. 1996. Women Managers, Gendered Cultural Processes and Organizational Change. Gender, Work and Organization.

[17] Gibert. 2010. Does Gender Matter? A Review of Work related gender commonality. Gender in Management: An International Journal.

[18] Brescoll, V.L., \& Uhlmann, E.L. 2008. Can an Angry Women Get Ahead? Association for Psychological Science.

[19] Boyson, L.A.E. \& Nkomo, S. M. 2010.Gender role stereotypes and requisite management characteristics: the Case of South Africa. Gender in Management: An International Journal.

[20] Carli \& Eagly. 2001.Gender, Hierarchy \& Leadership: An Introduction. Journal of Social Issues.

[21] Hayes, J. 2004. Intuition, women managers and gendered stereotypes. Personal Review.

[22] Eagly, A. H. 2001. The leadership style of women and men. Journal of social issues. 